Historic, archived document

Do not assume content reflects current scientific knowledge, policies, or practices. 

Inu Aruite Indured.

सrand

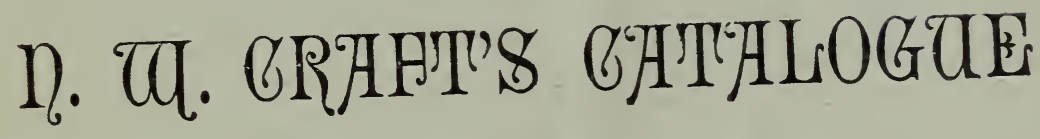

AND PRIGI LIST.

CEDAR COVE NURSERIES,

SHORE P. 0., YHDKIN COUYTY, N. C.

I 886 - I 887 .

त्याओ 



\title{
NEW DESCRIPTIVE CATALOGUE
}

\author{
AND PRICE LIST OF
}

\section{FRUIT TREES, VINES AND PLANTS,}

\author{
CULTIVATED AND FOR SALE AT THE
}

GeDHr Gove DURSERIES,

SHORE P. O., YADKIN CO., N. C.,

I 886 - - I 887

N. W. CRAFT, Proprietor.

SALEM, N. C.

BLUMS' STEAM POWER PRESS PRINT.

I 886. 


\section{INTRODUCTION.}

I have been engaged in the growing of Nursery Stock for more than thirty-five years, and for the past eighteen years making it my special business. Since 1879 ] have been sole proprietor of the Cedar Cove Nurseries, Vineyards, Fruit Garden and Experimental Orchards, and have, in order to meet the increasing demands, run up my stock to the amount of oyer Two Hundred Thousand Young Trees, Vines axd Plants. I now beg leave to present to my former patrons, friends and the public generally, my New Catalogue of Fruits. My patron. age has continued extensive, and my efforts to please and give entire satisfaction have been untiring. My facilities for supplying the fruitgrowing public with all leading and desirable varieties of Fruit 'Trees, Vines, Plants. \&c., both new and old, native and foreign, cannot be surpassed by any Nurseryman, either North or South. I wish to thank those who have purchased of me in the past, not only for their orders, but for the interest many have taken in my behalf by spreading the good reputation my trees, vines and plants bear among their friends. Everything is conclucted under the personal supervision of the proprietor, making it less liable for mistakes to occur; but mistakes will sometimes happen. Should any error be made in filling orders, my customers may feel assured it will be entirely unintentional, and on informing me of the fact I will promptly rectify it and make everything satisfactory, if it lies in my power to do so.

The principal portion of my Nursery Stock is located at Fus'T Hili, YadKix Countr, immediately at Shore Post Office, while my experimental Orchards, Vineyards, Fruit Gardens, \&c., are at my residence on the west bank of the Yadkin River, $1 \frac{1}{2}$ miles east of Flint Hill. Parties wishing to visit my Nurseries should call at my residence, where the proprietor, or an assistant, will conduct them through the various departments.

My prices will be found as low and as reasonable as those of any other first-class Nursery. Soliciting your orders, I remain,

Most respectfully yours

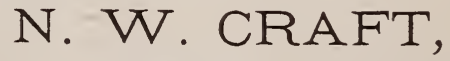

CEDAR COVE NURSERIES.

SHORE P. O., Yadkin Co., N. C. 


\section{N. W. CRAFT'S NEIV FRUIT CATALOGUE.}

NOTICE TO CORRESPONDENTS,

\section{ayasy}

Persons ordering trees by letter will save us much trouble by writing out the names of the different varieties ordered distinctly, in a list stating plainly where substitutions may be made, in which cases we will use our hest endeavors to give entire satisfaction. It is impossible for any nur seryman to keep up his assortment of all kinds, and it so happens with me sometimes, and I must claim the privilege, when out of some sorts to put in others equally as good. If you wish to plant largely of anything in this Catalogue, give me a list of all kinds and the number of each you want on a separate sheet of paper from your letter, leaving me room to annex prices, and I will return it to you with prices that I arn confident will prove satisfactory.

All packages of trees ordered from a distance will be packed in the best possible manner, and clelivered at the ne rest Railroad Depot, free of charge, except for boxes and packing material.

Our responsibility ends on delivery of the box at the Depot and taking the Agent's receipt for the same.

Parties faroring us with order's from a distance are requested to give plain shipping directions; when none are given, we will forward according to our best judgment. Orders from unknown correspondents must be accompanied by the Cash, Pest Office Money Order on Salem or Winston Post Office, or draft on the First National Bank, or Wachovia Bank, Winston, N. C.

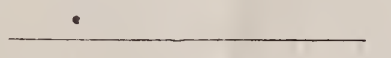

\section{TREES BY MAIL.}

I will send by mail, postage paid by me, small one to two feet oneyear Apple, Peach, Pear, Cherry, Apricot or Quince trees, well-rooted, at prices mentioned per dozen or tree in this Catalogue, when One Dollar's worth or more is ordered at a time, cut back only sufficient to be received in the mail. 


\section{HINTS FOR TRANSPLANTING.}

Fruit trees may be transplanted at any time from the first hard frost in Autumn until the buds begin to grow in the Spring, provided the ground is not frozen.

The ground should be previously prepared by deep and thorough ploughing; if loosened to the depth of eighteen inches all the better. The holes should be dug from three to four feet in diameter, and eighteen inches deep, so as to receive the roots without bending. The holes should first be partly fillerl with the best top soil, so that the tree may be planted only about as deep as it previonsly grew in the Nursery. The roots should be examined and all the wounded parts pared off smoothly with a sharp knife; shorten the tops more or less in proportion to size and variety of tree.

Hold the tree upright and extend the roots in their natural position and cover carefully with pulverized soil. which should be brought in contact with every fibre so as to leave no hollows or cavities among the roots. When the roots are perfectly covered, press down the earth firmly with the foot, leaning the tree a little to the South-west; then fill up the remainder of the hole without pressing, except near the stem where it should be firm. Stake securely to prevent rocking and chafing. In planting dwarfs, the entire stock below where the bud or graft was inserted, should be underground.

For fruit trees the soil should be dry, either naturally or made so by thorough drainage, as they will not live and thrive well on a soil constantly saturated with stagnant moisture. Any ordinary ground that will produce good crops of corn, wheat, tobacco or cotton, will grow good fruit trees.

It is highly necessary to keep fruit trees of all kinds under a state of annual and clean cultivation while young, to secure the best results. All sown crops are very injurious; the ground should be kept in some crop that requires clean culture, but should not be cultivated later than July. Potatoes, beans, peas, cotton or tobacco are very suitable. If corn is raised, do not plant within five or six feet of the trees. Mulching newly-planted trees is particularly beneficial. The ground may be corered from the stem of the tree three or four feet in width and four or five inches in depth with rough manure, straw or old hay. Leaves are a good mulching material and any rough litter that will retain moisture during the summer season will answer.

Tie a handful of straw around each young apple tree in Autumn and let it remain until spring. This keeps the rabbits from gnawing them. Keep all kinds of cattle off. At no time should they be allowed to browse upon young trees and vines. 


\section{TREATMENT OF TREES WHEN RECEIVED.}

Immediately on receipt of the trees open a trench one foot deep and two in width; unpack and lay the trees in the trench in an inclined position and cover the roots and stems about eight or ten inches above the collar, with loose, fine earth. Trees, if so protected, can, if received in Autumn, be preserved for Winter or Spring planting, if a high and dry situation is chosen.

All trees shipped in boxes and received in cold, freezing weather should be placed in a cellar (cool, but free from frost) and allowed to remain unpacked until thawed out. As soon as thawed unpack and bury in a deep and wide trench and let them remain for eight or ten days.

Should they arrive late in the Spring in a dry, shriveled condition, they should be buried in a deep trench and water freely applied, and remain in that condition for six or eight days.

\section{DISTANCE FOR PLANTING TREES.}

Standard Apples, 25 to 30 feet each way.

Standard Pears and strong growing Cherries, 20 feet.

Standard Cherries, Duke and Morello, 18 feet.

Standard Peaches, Plums, Apricots and Nectarines, 15 to 18 feet.

Quinces, 12 feet.

Dwarf Pears and Cherries, 10 to 12 feet.

Dwarf Apples, 6 to 8 feet.

Currants, Gooseberries and Raspberries, 3 to $b$ feet.

Grapes, 6 to 8 fèet.

Strawberries, in rows, 4 feet wide, 1 foot apart in row.

\section{NUMBER OF TREES ON AN ACRE WHEN PLANTED AT STATED DISTANCES.}

30 feet apart each way........................................ 49 plants.

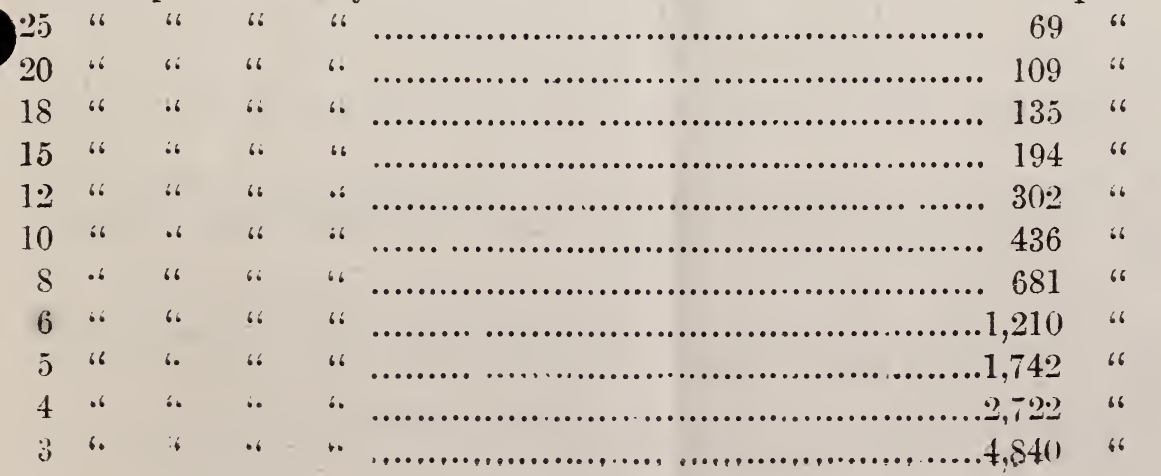




\section{SELECT APPLES.}

By planting a judicious selection of Summer, Autumn and Winter varieties, a constant succession of this much esteemed fruit can easily be obtained through the entire year.

Form low heads, not more than $t$ or j feet, which affords protection to the trunk against the hot Summer sun and the cold winds of Winter.

Dwarf Apple trees are being planted for ornament in gardens, on account of their great beauty when in fruit. I cultivate as dwarfs such as are of large fruit and most showy. Dwarfi on my grounds commence bearing at two and three years old and prorluce large and showy fruit.

The following list comprises the different varieties, most of which are cultivated in large quantities as standard trees for permanent orchards.

The descriptions may be relied upon as being accurate, having been compiled and classified according to the seasons in which they respectively mature. I can confidenty recommend my stock of trees, vines and plants as containing the best native and foreign kinds now in cultivation. With the proper care and attention it is easy now to have a good supply of green fruits the entire year as to have corn or wheat, since the many new late keepers have originated.

\section{PRICES, unless otherwise noted.}

St:undard Apples, 3 to 5 feet in height, 15 cents each, $\$ 12.00$ per 100$)$

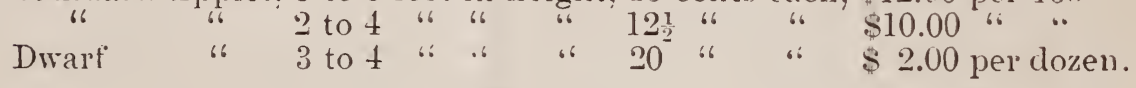

\section{Summer Varieties.}

American Summer Pearmain - Medium size, oblong; skin red, spotted with yellow in the shade; flesh yellow, tender, juicy and rich. August.

Early Harvest, or Yellow June-Medium to large : roundish, oblate: pale yellow, tender, sub-acid, fine flavored; tree morlerately vigorous and erect grower. Last of June and July.

May-Roundish, oblate, pale yellow ; pleasant, acid, juicy ; excellent for cooking. Last of May and through June.

Maiden's Blush-Large, oblate; pale yellow, with red shaded cheek ; tender, sub acid.

Maryland-Large, roundish, oblate; yellow ground, mostly covered with dark red stripes when fully ripe; flesh yellow, fine flavored, sub-acid, jyicy, tender, best. July and August.

Red June - Medium size, oval ; deep red, crisp, juicy, tender; tree erect, vigorous, and an early bearer, and should be in every orchard. Last of . June and first of July.

Red Astrachan-Large, roundish; deep crimson, overspreal with a thick bloom; juicy, rich, acid, July. 
Sine Qua Non-Size medium; pale yellow, with grey specks; flesh tender, high-flavored, excellent. July.

Summer Rose-Medium size, roundish, oblate; ground pale waxen yellow, covered with bright, crimson stripes; very tender, crisp, juicy, sub-acid. June and July.

Summer Queen-Large, conical ; striped and slıaded with red; rich and fine flavored. July.

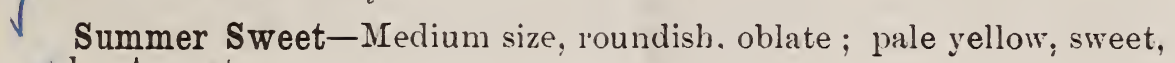
good. August.

Sweet Bough-A good summer apple; large yellow; flesh tender, sweet flarored; a strong grower. August.

Sugar Ball-Medium to large size, oblatə; yellow, flesh tender, very sweet and good. Middle of August.

Yellow Horse-Large, roundish, oblate : pale yellow ; flesh tender ; rich, juicy, with pleasant acid flavor. Good for cooking, stock or cider. August.

\section{Autumn Varieties.}

Aunt Sally - Medium to large size: pale yellow, with gray specks; tender, sub acid. September and October.

Buckingham-Very large, roandish; yellow ground, covered with dull red stripes: flesh tender, juicy, sub-acid, moderately rich. October and November.

Baltimore Red-Very large, round; dark red, with white dots ; flesh coarse, juicy, sub-acid. October and November.

Gravenstein-Tery large; greenish yellow, with bright splashes of red and orange; tree rigorous. September and October.

Golden Russet - Medium size; yellowish russet; flesh firm, crisp, tender, juicy, first-rate. October and November.

Harper's Seedling-A new and rery interesting apple: originated on the premises of the late Edgar Harper, of Forsyth County, N. C.; combining perhaps more good qualities than any other one of our fall apples (unless it be the Magnum Bonum, or Merritt). Medium to large size; roundish, oblate ; red, with white specks; flesh yellow, tender, crisp, juicy, rich, excellent flavor : vigorous grower, productive bearer and bear's young. October to January. Price 25 cents.

Magnum Bonum - Medium size, roundish, oblate: color red, with white specks; flesh vellow, tender, crisp, juicy, mild, sub-acid ; excellent rowth, vigorous and productive, and bears quite young. October and November.

Merit--Large, roundish, oblate: dark red when fully ripe, with white specks; flesh yellow, tenrler, juicy, sub-acid : very good. September and October.

$\checkmark$ Yadkin Beauty-A new, fine apple, originated in Yadkin County a few years back; of large size, round, oblate; yellow ground, covered with clark red stripes, frequently red all nver: flesh yellow, fine grained, only slightly acid ; likel by all who have seen it : tree very thrifty, and all abundant bearer. Oetober to January. Price 25 cents each. 


\section{Winter Varieties.}

Alleghany Seedling-Very large, roundish, oblate; skin bright yel. low, with green blotches; flesh moderately coarse, juicy, rich, sub-acid flavor. November to February.

Angell's Favorite-Introduced by Mr. D. D. Angell, of Yadkin Co., hence its name. Mr. Angell recommends it as the rery best of keepers, and says it bears some. fruit every year, and every other year it bears profusely. After having samples of the fruit that kept in my cellar until A pril of last year, I do not hesitate to recommend it as a very valuable addition to my stock of winter varieties. Fruit medium to large: vellow ground, splashed and marbled with bright red: flesh white, tender, juicr. inild, sub-acid; pleasant flavor. Claimed by Mr. Angell to be a valuable market apple. Tree hardy and thrifty grower. November to $A$ pril. Price 50 cents each.

Bowman's Excelsior-Large form, roundish, ovate ; color deep red in the sun ; flesh yellow, rather coarse, rich, juicy, very good ; tree a vigorous, upright grower. November to March.

Ben Davis, or New York Pippin-Large, roundish ; yellow gromd, splashed and marbled with bright red: tender. juicy, mild, sub-acid, pleasant flaror. Succeeds well over a great extent of our country. November to March.

Carolina Pippin-Fruit large, roundish; striped with yellow and red; flesh firm, juicy, and rich; growth vigorous. November to A pril.

Clark's Pearmain-Size medium, round, slightly conical ; skin red with numerous white dots; flesh firm and fine. November to January.

David's Winter--Medium to large size, reundish, oblate; skin yellow, covered mostly with dull red; fiesh yellow, tender, juicy, sub-acid; tree vigorous and abundant bearer. November to April.

Edwards-For description, see Darid's Wintel.

Foust-Medium size, roundish: bright yellow when fully ripe: flesh yellow, sub-acid. November to March.

Golden Winter-Large, roundish, oblate; deep golden yellow ; flesh firm, juicy, sub-acid: grows very thrifty and upright, bears abundantly. December to April.

Green Sweet-Medium size, somewhat conical; greenish yellow; flesh very tender and juicy, with a sweet, refreshing flavor. December to March.

Hall-Below medium size, roundish, ovate; skin dull red with white specks: flesh yellow, crisp and juicy. December to March.

Hewe's Virginia Crab-Small: dull red, dotted with white specks: a choice cider apyle. November to January.

King (of Tomkins County)-A red apple of large size and fine qual ity; tree a grood grower; hardy. November to March.

Limbertwig Red-Medium to large, roundish; skin rlull, rusty red: flesh yellow and flrm, rich, sub-acid; much admired; tree thrifty, good bearer and great keeper. December to April.

Limbertwig Royal-Very large. round, oblate: pale rellow, striped with red: flesh yellow, rich, juicy and of the very best flaror. One of the very best very large winter apples. Tree a very thrifty grower, forming a fine, hardy tree; good bearer. December to March, 
McCuller's Winter-Claimed by its introducer to be one of the best keeping apples. Size above medium : red, with a yellow ground, specked: oblong shape. Is claimed to keep without extra care until very late in the Spring. Price 50 cents.

Mattamuskeet-Medium to large, roundish, oblate; skin rusty red with white dots; flesh yellow, tender, sub-acid, rich and excellent. December to April. Should hang on the tree until after some frost.

Nansemond Beauty-If this apple proves ta be what its introducers claim, it will be one of our most valuable winter apples. Price 25 cents each.

Neverfail (Rawl's Jannet) - Medium size, roundish : skin yellow. with dull, brick red; flesh rich, mild, sub-acid, juicy and good. (Often rots badly. December to April.

North Carolina Keeper-A new variety, introduced from Davidson County, of superior keeping qualities, retaining its fine, rich flavor and its crisp, juicy texture in an eminent degree all through the winter and spring, slightly sub-acid when fully mellow. Size medium, yellow ground. covered with beautiful crimson stripes; strong grower and extremely prorluctive hearer, fruit growing in perfect clusters along the limbs. It was placed on exhibition at the last meeting of the $\mathrm{N}$. C Horticultural Society, at Raleigh, N. C., and unanimously recommended as a superior keeping and market apple. Feason January to May. Price 25 cents each.

Pryor's Red-Medium to large, roundish ; skin yellow, shaded with red and striped with dark crimson; tender, juicy, sub-acid flavor. December to April.

Red Cheese-Probably no apple has become more popular on its own merits than the Red Cheese. Medium to large, irregular, oblate: yellow ground, covered with beautiful red crimson ; flesh yellow, sub-acid: of superior quality ; bears immense crops.

Romanite-Medium size, roundish, conical ; skin purple red on light yellow ground: flesh tender, rich, fine-grained, acid scarcely discernable: branches pendant. October to February.

Shockley-Medium size, roundish, conical; greenish yellow, ground covered with red; flesh yellow, fine-grained, sub-acid, crisp, juicy and rich. December to A pril.

Vandevere-Medium size, round, oblate: pale red stripes on yellow ground, deep red on the sun side; flesh yellow, mild, sub-acid. Decem. ber to April.

Virginia Beauty-Large, roundish, conical: skin a beautiful purplish red; flesh tender, crisp, juicy, very good. December to March.

Virginia Cheese-Large, oblate; skin greenish yellow; tender,juicy, fine flavored; tree upright, vigorous. November to March.

Vanhoy-Medium to large, oblate, conical; nearly covered with rich, lively red stripes: flesh yellow, firm, crisp and juicy, with a rich flavor: good keeping apple (new). Price 25 cents each.

Wine Sap-Large, roundish: deep red with a few streaks: flesh rellow. firm, rich and crisp : a profuse beares: a valuable southern apple. There is perhaps no apple which deservedly receives more praise over a large extent of country than this. Norember to May. 


\section{Crab Apples. \\ FOR ORNAMENT OR PRESERING}

Red Siberian Crab-small, one incls in cliameter: yellow, with crimson cheek. November to December.

Yellow Siberian Crab - small, of a rich amber or golden yellow color. September to Novemcler.

\section{PEACHES.}

The Peach tree will grow and thrive on all high, well-drained soils with good, clean culture. A moderately rich, sandy loam is probably
the best.

The trees should be headed low ; cut back early in spring after transplanting, within two or three feet of the ground: cut back annually all strong growing branches one-third, weak ones one-half.

The trees should be examinerl twice a year for the boler, an injurious worm which clepredates upon peach trers at the collar. In the Spring remove the soil and cut out the borer with a knife; replace the soil, hilling up the tree about one foot high, to be remover in Autumn, say about the last of November. placing a peek of leached or half a leck of un-

Peuch-growing is lach tree. early varieties have been largely on the increase since the many new, fine by the Joth of June and a succession unt we can now have ripe peaches

\section{PRICES, unless otherwise noted.}

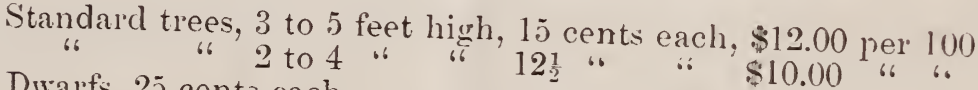

Dwarfs, 25 cents each.

Clingstones designated by C'; Freestones by F.

\section{Varieties.}

Albright's Late, $\mathbf{C}$-The value of this peach is its great keeping qualities. Medium to large size and fine appearance. Octobcr aud No-

Alexander (Early,) F-Mediumi to large: of a deep maroon shade, covered with the richest tint of crimson. and beautifully dark striped, changing toward the light side to a rich orange; one of the earliest peaches in cultivation, ripening from 10 th to last of June.

Amelia. F-Large size, roundish oval; pale, yellowish white, with a beautiful red cheek; rich, juicy, excellent. Middle of July.

Amsden's June -- A beautiful early peach, much resembling the Alexander in appearance and quality, and ripening at the same time.
Very desirable.

Bellegarde, F-Fruit large. round: skin pale yellowish green with crimson cheek; fine, melting and juicy. Last of July and first of August, 
Baltımore Beauty, F-Size medium; yellowish, with a bright red cheek. First half of July.

Bergen's Yellow, F-Large, round and regular ; skin deep orange. cheek dark red; flesh deep yellow, melting; juicy and rich. First half of August.

Blood-Leaved Peach-This startling norelty is worthy of a place in every collection of ornamental trees. The leaves are of a dark purple color, like the "purple-leavdd beach," changing from Spring to Autumn from a deep purple to rarious colors as the season adrances, becoming of a lighter color till the end of the season. The bark on new wood and fruit is purple like the leaves.

Chinese Cling, C-Very large, roundish, oval; skin transparent. cream color, marbling of red next the sun; flesh creamy white, very juicy and melting. Midclle of August.

Comet-Claimed to be an extra fine peach; not tested here. Price 25 cents each.

Crawford's Early Melocoton, F-A very large, oblong peach : skin bright yellow with red cheek; flesh yellow, juicy and very good. August.

Crawford's Late, F-Large size; skin yellow, with dull red cheek; flesh yellow, but red at the stone: excellent. Last of August.

Catherine Cling, C-Large, roundish : skin yellowish green, sprinkled with red specks, cheek bright crimson; flesh firm, juicy. Middle of August.

Delaware Rarerpe, F-Large, roundish : skin white with a bright red cheek; flesh white, rich, juicy and gnod. First half of August.

Downing-Prized by many, but we do not consider it equal to some other early varieties. Ripens about the same with other classes of early peaches. Price 25 cents each.

Dyer's June-A beautiful, very early peach, resembling the Farly Alexander in size, but was claimed by the originator to be much earlier: has proved here but very little earlier. One of our very best early peaches, ripening early in June. Price 25 cents each.

Early Beatrice-Medium size: with a marbled red cheek, flush, melting and very juicy; ripens the last days of June and first of July.

Early Louise, F-Medium size ; bright red ; very juicy and excellent. This is nearly as early as the Beatrice.

Early Rivers, F-Large ; color pale straw, with a delicate pink cheek. flesh melting; flavor rich; one of our best family and market peaches, and growing in faror yearly. First of July.

Early Tillotson, F-Medium size, oblong; skin creamy white, nearly covered with lively red; flesh whitish, but red at the stone, melting, rich, rery juicy and fine Middle of July.

Early York, F-Medium size; skin rer' thin: pale red, thickly dotted with red over a pale ground, but quite dark in the sun : flesh very tender, rich and juicy. Middle of July.

Eaton's Golden Cling- Large, round; skin dleep orange: flesh firm and juicy. One of our rery best and reliable late peaches. First of October.

$\checkmark$ Foster Peach, F-Large, yellow, fully as large as Crawlord:s Early. the fruit running uniform in size and ripening a fow day earlier than Claw ford is Early. 
French, C-Medium size ; of French origin : very distinct in foliage and bloom from all native peaches, the bloom being perfectly white and the young shoots of a greenish yellow. Fruit, skin and flesh yellowish white: very juicy, melting, nder and rich. Last half of August.

Governor Garland-Is a medium size clingstone peach of a beautiful, rich, mottled red color. It is very firm and bears transportation well. For earliness, color. flavor and shipping qualities combined, the world will hardly produce its superior. Tree hardy, bears large crops. Price 25 cents each.

Hale's Early, F-Medium size, round; skin white with deel' red cheeks; flesh white, rich, juicy. Middle of July.

₹ Harris's Winter - A firm, late freestone from Eastern Carolina. Flesh white, tinged with red; good size and fine quality for so late a peach. Neason last of October and first of November. Price 25 cents each.

Heath's Cling-Fruit very large: color creamy white : flesh white, juicy, melting, tender and rich. September.

Heath's Freestone-Large size; greenish white, purplish red cheek: melting, juicy, sub-acid flaror ; tree vigorous and productive. Last of August and first of September.

George 4th, F-Large size: skin white, dotted with red specks, with a soft red blush next the sun; flesh juicy and rich. Last of July.

Large Early York, F-Nedium; white with a red cheek; flesh juicy and delicious; tree vigorous: an excellent variety. Middle of July.

Lord Palmerston - A magnificent, large, very late peach. Flesh remarkably firm, deeply stained with red at the stone, and slightly adherent, richly flarored. This is claimed to be the iargest late peach in culti. yation. Price 25 cents each.

Mitchell's Mammoth, C-Very large; skin creamy white, with a pale cheek : flesh white, fine flavored, excellent: seerls sinall. First half of September.

Morrisania Pound, F-Quite large : skin creamy white with a dark red cheek: flesh cream colored, jnicy and rich. Last half of August.

Mountain Rose, F-Medium to large ; skin cream colored with red cheek; flesh tender, juicy, excellent. Last of .July.

Musser-A very handsome peach, and of excellent flavor; a firstclass variety in every respect. One of our very earliest varieties. Price 25 cents each.

Orange, C-Large, round: skin deep orange with a red cheek ; flesh deep yellow, firm, juicy and rich. August.

Old Mixon, C-Large; skin and flesh creany white, some blush next the sun; very juicy and melting.

Old Mixon, F- Large; skin cream colored with red cheek; flesh tender, juicy, excellent. First half of August.

President, F-Very large: skin yellowish green with a red cheek: flesh juicy, deep red at the stone, excellent. Last half of August.

Red Cheek Melocoton, F-Lalge size: -kin yellowish, with a red cheek: fiesh pale yellow, juicy and rich, tugust, 
Richmond, F-Large; yellow, somewhat mottled with dark red; flesh yellow, juicy, rich. Last of July.

Royal Kensington, F-Fruit large, roundish, somewhat depressed; skin white, with a red cheek, juicy and good. Last of July.

Steadly-A very fine, large, new late white peach of exquisite flavor. 'Tree hardy, rigorous and prolific.

Stump the World, F-Very large, creamy white, with a bright red cheek; flesh juicy and high flavored; very productive. First of September.

Sallie Worrell-This extremely large, magniticent peach is a native of North Carolina. Flesh white, juicy and of a delicious flavor. Tree vigorous and good bearer. Ripens first of August to first of September. Price 25 cents each

Saunders-A new seedling peach, originated in Lancaster County, Penn. Of the character of the Early Alexander and Amsden, ripening about the same time; comes well recommended, and after thorough trial find it one of our very best early sorts. Price 25 cents each.

Thurber, F-A universal favorite, as it is a profitable market peach of excellent flavor and fruit of the largest size, very handsome and separates freely from the stone. Ripens about the middle of August.

Waterloo Peach-A new and remarkably fine very early peach, claimed by the introducer to ripen two weeks earlier than the Alexander; of larger size and equally fine appearance. It proves only about as early as the Alexander here; of extra good quality. Price 25 cents each.

Wheatland - Fruit large ; flesh yellow, very juicy and of most excellent flavor; separates readily from the stone. Ripens between Early and Late Crawford. Regarded by some peach growers as one of the most valuable varieties. Price 25 cents each.

White Indian Cling-Very large, roundish, oval ; skin transparent, cream color, with marbling of red next the sun : flesh creamy white, very juicy and firm; new. Last of August. Price 25 cents each.

Wager-This new peach is recommended by those who have tested it to be one of the best, without exception, for table use and canning purposes, being very rich, thick-meated; small pit and of a golden yellow color ; very hardy and one of the most abundant bearers known. As it is taken from the can its taste is more like the fresh peach from the tree than any other variety known perhaps. Price 20 j cents each.

Wilder-A new early peach, originated in Pennsylvania, remarkably strong and healthy grower. Fruit medium size; skin white with deep rerl cheeks; Hesh white, rich, juicy. Claimed by the originator to ripen equally as early if not earlier than the Alexander; has been thoroughly tested and proves all that was said of it. Price 25 cents each.

$\checkmark$ Yellow Alberge, F-Fruit large; skin yellow; with a dark red cheek; flesh yellow, juicy and fine flavored. August.

Yellow Rareripe, F-Fruit rounded, oval; skin leep yellow with crimson cheek : flesh yellow. First of September. 


\section{Dwarf Peaches.}

Golden Dwarf-'This peach is highly ornamental on account of the small growth of the tree; its leaves add much to its beauty, being of a dark green, and remain on the tree till quite late in the season. Fruit about medium size ; of a beautiful yellow color, with a rich and mottled skin. September. Price $2 j$ cents each.

Italian Dwarf, F-This will commence bearing at not more than 18 inches high, and is said to seldom exceed four feet. Fruit of medium size; greenish white ; flesh white and juicy ; foliage rery clark and thick, of a deep green. September. Price 25 cents each.

The Dwarf Peach we can only recommencl as an ornamental bush for gardens, fc.

\section{PEARS.}

The culture of the pear is rapidly extending over the country as its value is more appreciated.

By making a judicious selection they can be har in good eating condition throughcut the Summer, Autumn and Winter seasons.

The pear is surpassed by no other fruit for its fine quality, its melting juicy texture and refined flavor; and being one of the most beautiful of fruits, should give it a place in every fruit garden or orchard in the land. Budded on its own stock it makes a standard tree adapted to large permanent orchards, that will, with good cultivation, come into bearing as early as Standard Apples, and some varieties earlier. Budded on the French or Angers Quince it makes a dwarf that will come into bearing the second or third year after planting, requiring garden culture and severe pruning every year; such as thinning out the top and side branches. The pear succeeds best on a deep, rich. dry soil, trainerl with low heads, cut back at time of planting, standard three or four feet from the ground and dwarf one to two feet. Gather when on gently lifting the firut the stem will readily separate from the limb, and place in a dark, dry room until fully matured. Winter pears should hang on the trees until there is danger of frost; then they may be gathered and placed in a dry cellar for maturing, and are easily kejt by careful handling until March and April.

\section{PRICES, unless otherwise noted.}

$\begin{array}{llllll}\text { Standard trees, } & - & - & - & 50 \text { cents each, } & \$ 5.00 \\ \text { Dwarfs, } & - & - & - & 40 \text { per dozen. }\end{array}$

\section{Summer Varieties.}

Bartlette-Fruit large ; yellow ; flesh juicy, rich, buttery and very melting; tree erect, vigorous grower, early and profuse bearer. August to September.

Belle Lucrative--Fruit rather large, obovate; skin pale yellow, slightly russeted; flesh very fine and melting; tree upright, vigorous. August. 
Bloodgood--Medium size ; melting, buttery and rich, of first quality ; good grower and abundant bearer. First of July.

Clapp's Favorite-A large pear. resembling the Bartlette; pale yel low, with brown dots ; very productive. August.

Comet, or Lawson-A new variety, valued for its earliness, size and exquisite beauty. The points of merit claimed for it by introducers are: a vigorous, upright grower : an early bearer: rery productive: a good shipper; the earliest large jear : the most beautiful: the most saleable and a gnod eating pear : its color being bright yellow, and the inost brilliant velmillion next the sun, and although not of the highest quality, yet fairly good; it is of good size and ripens first of July. Price \$1.00 each.

Doyenne D'Ete ) Summer Doyenne)-Small, roundish ; fine yellow, often with bright red cheek in sun; flesh white, melting, juicy, sweet, pleasant; always ripens by 20 th and 25 th of June; tree an upright, vigorous grower and early and abundant bearer ; this is the first to ripen of the really good pears.

Frank Real-Medium size; juicy, melting and rich; tree hardy, vigorous and productive. July.

Flemish Beauty-Large, abovate; skin dull yellow, more or less russeted, with a brownish blush: flesh fine-grained, melting, sweet and rich. August and September.

Henry 4th-small, roundish; greenish yellow : very juicy and melting; stout grower and profuse bearer. August.

Kieffer's Hybrid-Claimed to be a famous pear ; somewhat Bartlette shaped; tree hardy, claimed to be blight proof; an abundant bearer, producing fruit when only two and three years old: is becoming very popular and ripens about the first of September. Price $\$ 100$ each.

Le Conte-A new pear that has become very popular on account that it is clained to be blight proof. The tree gaows very upright and very rapidly, with large light green, glosiy leaves and green shonts. It is claimed for it that it has no off-year, but bears every year. Fruit bellshaped; of a rich, creamy, yellow color, with a handsome blush; ripens in July and August, and is a great shipping pear; but the flesh and flaror will hardly equal many of our very fine pears. Price $\$ 1.00$ each.

Louise Bonne de Jersey-Large, pyriform ; skin pale yellowish gref $\mathrm{n}$, with a dark red cheek; melting, buttery and rich. August and September.

Rostiezer-Medium size: skin a dull yellowish green, with a reddish brown cheek; flesh juicy, very melting and sweet. August and Lept.

Seckel-Small size ; yellowish brown, with a red cheek : flesh buttery, juicy, melting, with a rich aroma; the richest and most exquisitely flavored pear known; tree a stout erect grower, and a regular and abundant bearer. September.

Tyson-Medium size; greenish yellow. with a red cheek; flesh melting and fine. August.

White Doyenne-Fruit medium to large, obovate; skin pale yellow, sprinkled with small dots: flesh very fine and white, melting, buttery and rich. September. 


\section{Autumn Varieties.}

Beurre Diel-Very large, pyriform; skin orange yellow, marbled with russet; flesh buttery, rich, sweet. September.

Beurre Clairgeau - Very large, pyriform; yellow and dull red; melting, juicy and high flavored; a vigorous and robust grower and early and good bearer. October and November.

Beurre d'Anjou-Fruit large, nearly globular'; skin greenish,sprinkled with russet, and sometimes with a red cheek; Hesh melting, perfumed and excellent; tree vigorous and productive. October and November.

Beurre Bosc-Large, long, tapering to the stalk; skin dark yellow, nearly covered with cinnamon russet; flesh white, melting, very buttery, with a rich and excellent flavor. September.

Buffum-Medium size; deep yellow, suffused with bright red; flesh buttery, juicy, sweet and excellent; tree a vigorous grower. End of September.

Duchess d'Angoleme-Fruit of the largest size; forn oblong, obovate, with an irregular, uneven surface, skin greenish yellow; clouded with russet; flesh yellow, juicy and rich. September and (october.

Doyenne Bussock-Fruit large, obovate; skin rough, yellow, clouded with russet; flesh very juicy, sweet and aromatic: tree vigorous and an abundant bearer. September and October.

Edmund's - Very large; lemon yellow; fine flavor; vigorous and productive. September.

Frederick of Wurtemberg-Fruit large, one-sided, pyriform; skin deep yellow, with a crimson cheek; flesh white, very juicy, melting and sweet. September.

Howell-I Large; light, waxen yellow; flesh melting, swret and rich ; a vigorous grower and profuse bearer. September and Uctober.

Maria Louisa-Large, pyriform; skin yellow, clouded with russet: flesh fine grained, buttery and melting; bears young. Septenber and October.

Napoleon-Large; light green, changing to pale yellow ; very juicy and melting. September to October.

Paradise d'Automne-Large ; yellow, mottled with cinnamon russet : flesi juicy, melting, rich and high flavored; a good bearer.

Souvenir du Congress-Of large size; beautiful yellow with bright red in the sun; melting, juicy, musky, ripening in September; new and highly commended by all who have tried it. \$1.00 each.

Stephen's Genessee-Large, roundish; flesh very juicy and melting : tree vigorous and productive. September.

St. Michael-Large; yellow and red; handsome, melting and goor : tree beautiful, erect, pyramidal. November.

Swann's Orange (Onondaga) - Very large, tapering bot? ways from the middle; skin fine, rich, yellow, covered with lusset dots; flesh buttery and melting. September and October. 


\section{Winter Varieties.}

Beurre Easter-Very large, roundish, ovate; skin yellowish green, sprinkled with russet; flesh fine-grained, buttery, melting and juicy; fine keeper, very desirable, and keeps until March and April.

Doyenne d' Hiver d' Alencon or Nouveau-Medium; yellow, shaded with crimson; flesh buttery, juicy, very rich and sprightly; a good bearer. December to A pril.

Glout Morceau-Fruit above medium size : skin greenish yellow with a brown cheek; flesh white with a rich flavor. Early Winter.

Josephine de Malines-Merlium size, roundish; skin yellowish, sprinkled with russet; flesh juicy, sweet and perfumed. December.

Lawrence-An American pear of great excellence; fruit medium size, obtuse, pyriform; skin fine yellow; flesh juicy, sweet and good; tree hardy, vigorous and very productive. December.

Mount Vernon-Full medium to large, nearly globular; color a rich cinnamon russet, with a reddish cheek; flesh juicy, crisp, melting, with a spicy, vinous flavor. November and December.

Pound-Very large; yellowish green with a brown cheek when long kept; flesh coarse, breaking and solid; good only for baking and preserving; tree vigorous and productive. December to March.

Salem-Crafts of this remarkably large keeping pear were handed to our agent many year's ago in Salem, North Carolina, for us to test in our experimental grounds the many good qualities which were claimed for it. The grafts had no name, hence its name "Salem." After" a thorough test we feel safe in recommending it to our patrons. Fruit very large size, round; yellowish green, changing to a beautiful yellow, sprinkled with russet when mellow; flesh firm, fine grained, juicy, rich; a fine keeper. January to June

This pear was exhibited at the late meeting of the North Carolina Horticultural Society, at Raleigh, N. C., and unanimously approred.

Winter Nellis-Medium size; yellowish; flesh buttery,juicy, melting and sprightly flavor; a straggling grower, hardy and productive. November to January.

Vicar of Wakefield, or Le Cure-Tery large, oblong; pale yellow, flesh juicy, sometimes buttery, with sprightly flavor: tree vigorous and productive. November to January.

\section{STANDARD CHERRIES.}

The Cherry will grow and thrive in a variety of soils; a dry, sandy or gravelly loam is best. Where it is forced to grow in wet places it is short lived.

The Cherry is a handsome fruit tree, and is susceptible of being trained in any form that taste or circumstances may require, and the fruit is a fine, delicate dessert. The acid varieties are highly esteemed for preserving and cooking purposes, and when dried command a high price: quite an income to many families is derived in this county (Yadkin) from the product of their cherry orchards. 
Hearts and Bigarreaus are rapid-growing trees with large, glossy foliage and sweet fruit, and are very desirable for yards and roadside trees and should, therefore, be chosen hy planters who are desirous of combining the useful and the ornamental; its symmetrical form, its rapid growth, its fine shade and beautiful blossoms, is exceedingly well suited for a yard or road side tree. We wish we could induce the planting of avenues of this and other fine-growing fruit trees throughout our country neighborhoods, as history gives an account of the beautiful custom in Germany, affording ornament and a crateful shade, and refreshment to the trav. eller, at the same moment. Our immense stock and low prices enables any one to plant standard cherry trees in quantity.

Dukes and Morellos are generally acid, though some varieties are of a mild, pleasant flavor. The trees are naturally of smaller and slower growth, but equally productive, bearing heavy burdens of fine fruit almost annually.

\section{PRICES.}

50 cents each.

$\$ 5.00$ per dozen.

\section{Hearts and Bigarreaus.}

Amber Bigarreau-Medium size; amber, covered with red in the sun ; flesh half tender and sweet. June.

Black Eagle-Itarge; black, very tender', rich, highly flavored. June.

Black Tartarian - Very large; purplish black; tender, mild and pleasant; an upright, strong grower and very productive. May.

Coe's Transparent - Medium size: pale amber, mottled with spots of red; very tender, sweet and juicy. I Last of May.

Dr. Wiseman-Believed by some to be the Doctor cherry described by Downing, and which originated with Dr. Kirtland, of Cleveland, Ohio, and is the earliest cherry, I have no doubt that is now in cultivation. Fruit medium to large; light yellow, changing to a beautiful bright rerl when fully ripe; flesh rather firm, juicy, sweet, rich, with excellent flavor, very much such a cherry as Goremor Wood. First of May.

Early Purple Guigne-Medium size ; reddish purple, tender, juicy and sweet; hardy and productive. May.

Elton-Large; pale yellow, streaked and mottled with red in the sun, half tender, juicy and delicious; tree vigorous, spreading and productive. June.

Florence-One of our largest cherries ; fruit roundish, heart-shaped, pale amber, mottled or mostly covered with bright red; flesh firm, rich, sweet, fine flavor, very good, ripening the first part of June.

Governor Wood-Isarge size; light yellow, shaded with bright red; flesh juicy, sweet, rich and delicious; a vigorous grower and very prolific. May.

Knight's Early Black-Large; black, sweet, tender and juicy; tree quite vigorous and a good bearer. Last of May.

Montreuse de Mezel, or Great Bigarreau-Very large ; dark brown, flesh firm and juicy; tree a fine grower and productive. May.

Napoleon Bigarreau-Large; white with red cheek; very firm and juicy. June.

Yellow Spanish-I Large; yellowish white, with occasionally a red cheek; juicy, sweet and excellent; tree vigorous and productive. June. 


\section{Dukes and Morellos.}

Belle de Choisy - Medium size; amber and red; tencler, melting and sweet; one of the most delicious cherries ; tree upright and symmetrical. May.

Early Richmond-Medium size; bright red ; flesh tender, juicy and somewhat acid; unsurpassed for cooking and preserving; tree a profuse bearer and very hardy. May.

May Duke-Medium size ; dark red ; tender and juicy ; tree a strong grower and very productive. May.

Reine Hortense (Monstreuse de Bavay) - Large; bright red; flesh tender, juicy, sweet and delicious; tree vigorous and prolific. June.

\section{Dwarf Cherry.}

The Cherry is dwarfed succcssfully by budding or grafting our fine varieties on the French stock, Mahaleb Cherry Seedlings, which flourish in nearly all soils, coming into bearing when but a small bush. The Dwarf Cherry has as yet been cultivated to a limited extent in this country, but on account that it is seldom we see a more beautiful sight than a plot of Dwarf cherry trees, not more than three and six feet high, with their branches loaded with beautiful ripe cherries, they are now growing in favor ; they should be trained with very low heads and can be successfully grown, planted five to eight feet each way. All the rarieties of cherries in our list are glown as dwarfs -50 cents each.

\section{PLUM.}

The Plum tree is not subject to disease, and will therefore succeed on a variety of soils. The Curculio is the only drawback to plum culture.

\section{PRICES.}

25 cents each.

$\$ 2.50$ per dozen.

\section{Varieties.}

Blue Gage - Fruit medium size, roundish, oblong; flesh yellowish purple, juicy, rich and excellent. First half of August.

Duane's Purple - Fruit very large, oral; skin reddish purple and juicy. August.

Damson Plum - Medium size, roundish, oblong; purplish black; - acid, fine flavored, good for drying, preserving, \&c.; very prolific bearer. September.

General Hand-Very large, roundish, oval; skin pale yellow ; flesh coarse, sweet and pleasant. August.

Italian Prune-Fruit medium, oval; skin dark blue with a bloom; flesh dark yellow, juicy. sweet and good. August. 
Lombard-Medium size, roundish, oval, slightly flattened at each end; skin violet red, paler in the shade, dotted with red and dusted thinly with bloom; flesh yellow, juicy and pleasant. August.

Orange-Fruit large, oval; skin deep yellow; flesh coarse; tree vigorous and productive. August.

Scarlet Gage-Rather below medium size ; scarlet color; flesh yellow, melting, sweet and excellent. August.

Shropshire Damson-A plum of fine quality and as free from the attacks of the curculio as the common Damson; of same color. The flesh is juicy and sprightly ; very productive. September.

White Imperial-Fruit above medium size; skin pale green till ripe, when it is tinged with yellow, showing a transparent marbling of shaded green stripes; flesh juicy, rich, and delicious. First of August.

Wild Goose- - This variety I wish to recommend especially to my customers, as a variety peculiarly adapted to the climate and soil of the Southern States. Large; skin red with fine bloom; flesh juicy, sweet; adheres to the stone. Last of July.

\section{APRICOTS.}

The Apricot succeeds well budded on the peach or wild plum, and will thrive well on any soil sufficiently dry for the cultivation of other stone fruits.

\section{PRICES.}

25 cents each. $\$ 2.50$ per dozen.

\section{Varieties.}

Breda-Medium size; skin deep yellow; flesh, rich, juicy, and very high fiavored. Last half of June.

Early Golden (Duboys)_Small ; pale orange ; juicy and sweet; hardy and productive. First of July.

Moorpark-Very large; skin deep yellow; cheek pale red next the sun; flesh deep yellow, rich and melting. Jaly.

\section{NECTARINES.}

The Nectarine is a mere sport of nature, or rather variety of the peach. Its perfectly smooth skin and waxen color, recommend it as one of the most superb of dessert fruits.

\section{PRICES.}




\section{Varieties.}

Imperial-Large size ; skin beautiful, transparent, white; flesh white, very tender and juicy. August.

Stanwich-Large; deep yellow, with a dark red cheek; melting, juicy and rich; a superb variety. August.

\section{QUINCES.}

The Quince tree is ornamental, hardy and may be planted with profit. It is an excelledt fruit for preserving and when dried they are fine for pies, tarts, \&c. It succeeds best on a deep, rich soil, heavily mulched during the summer, but will grow on almost any soil that is well enriched, producing beautiful fruit, ripening in September.

\section{PRICES.}

25 cents each. - - $\quad$ - $\quad \$ 2.50$ per dozen.

\section{Varieties.}

The Orange Quince, or Apple Quince, is very large, of a rich, golden color and very productive. This is the most profitable variety.

\section{ESCULENT ROOTS.}

ASPARAGUS.-Conover's Collossal-Very large and of excellent quality. $\$ 3.00$ per hundred.

RHUBARB, or PIE PLANT,-Iinæs (Myatt's)-Large; best of all. 25 to 50 cents a plant.

\section{AMERICAN SWEET CHESTNUT.}

The Chestnut makes a beautiful shade tree in lots devoted to grass for pasture or road sides, or is a nice yard tree; a desirable tree for any place where a shade tree is desired, combining the useful with the ornamental, as the chestnut bears immense annual crops of swert nuts. which is great sport and pleasure for the children to gather in during November of each year. Price, 1 to 2 feet. 25 cents ; 2 to 4 feet, 50 cents each. 


\section{GRAPES.}

The culture of the vine is lately receiving a good deal of attention in our country, and the many vineyards which have been planted for winemaking, as well as for table fruit, prove how admirably our soil and climate are adapted to the growth and perfection of the grape.

The magnificent shows of fruit at our State fruit fairs, held at different places in and since 1882 , show the great interest our people are taking in the cultivation of the finer fruits.

The display of grapes from these Nurseries and Vineyards in August, 1882, at Greensborough, was then generally acknowledged to be the finest ever before made in this State, and as a proof they received the two high. est premiums (\$20 in gold) offered for grapes : first, for the largest and best collection of grapes grown by one exhibitor: second, for the six best varieties, twelve bunches each : and at every Fruit Fair since,-at Wilmington in 1883, Goldsborough in 1884, and again at Greensborough in 1885 ; at the Wheat and Cattle Fairs at Winston in $18 S 3$ and 1884 , and at the Raleigh State Exposition and Fair in 1884, the fruits from this establishment were placed upon the tables and received flattering premiums and diplomas.

Many varieties of great value and peculiar adaptedness to our soil and climate have recently been introduced, and are supplanting many of the older and worthless kinds, and now with a due regard to selections of varieties every one may be able to grow this very clesirable fruit successfully and of the finest quality.

The culture of the vine is among the most ancient horticultural in. dustries of which we have any account, and although comparatively new with us, there are no reasons why it should not succeed and become in a short time one of our most pleasant and profitable industries.

To grow grapes successfully give vines a good, deeply dug or plowed soil; plant deep, at a reasonable distance apart. For moderate growers plant in rows seven feet apart and vines six feet apart in the rows ; for strong growers eight by eight feet. For arbor training the Scuppernong is undoubtedly the proper vine.

I cannot attempt in this catalogue to give a detailed account of the best manner of training and pruning vines, making wines, \&c., as that would require a book of itself; but will say here that I use posts of any reasonable size, six feet long, sharpened and driven in the ground, leaving the post about four and a half feet above the ground, one post at or he= tween each two vines. I then stretch a No. 12 or 14 galvanizerl wire six inches below the top of each post and fasten the vine which ought ta have two arms to each vine at the third year from planting; tie these arms to the wire and place a 12 or 15 inch wide plank on the top of the posts from one end of the row to the other, with one ten penny nail in each post to hold the plank to its place. The plank answers as a pro: tector against rain, hail, heavy dews, frost, \&c. My grapes have been grown on this plan for more than 15 years without a single failure during the time. If wire cannot conveniently be procured, a lath of some dur' able kind of wood nailed on the post will answer the purpose. 
Bushels of grapes might annually be grown on the sides of farm. houses, barns and out-buildings which are not otherwise occupied, rendering the building more comfortable in summer by the foliage of the vines, lequiring very little labor or expense and utilizing land that would otherwise be wasted.

In pruning the vine plenty of bearing wood should be left of the previous year's growth. Any one who engages in the Grape culture, if only a few vines for family use, will soon learn the character and wants of the vine both in pruning and culture.

\section{PRICES, unless otherwise noted.}

25 cents each. $\quad \$ 2.00$ per dozen. $\quad \$ 8.00$ per hundred.

\section{Varieties.}

Adirondac-Bunch large ; berries tender and sweet; vine moderately vigorous.

Allen's Hybrid-Medium size; light amber color; skin thin and of a rich, delicious flavor, early. Price 50 cents each.

Agawam - Bunch large, compact, of en shouldered; berries very large, roundish; skin thick; pulp soft, sweet, sprightly; of peculiar aromatic flavor; color dark red; vigorous growth.

Antionchon (Arnold's Hybrid, No. 5) - Bunches very long, not heavily shouldered; rather loose herries; medium size, round; greenish white flesh; melting and agreeable flavor; sprightly. Ripens with the Delaware.

Bacchus-Healthy, hardy and productive vine; highly recommended as a wine grape. Price 50 cents each.

* Brighton-Bunch large and beautifully formed; compact, shouldered; berries above medium to large; round ; coppery red color. Quality and flavor very superior. Price 50 cents each.

Black Hawk-A seedling from Concord; extremely vigorous. Price j0 cents each.

$\checkmark$ Catawba-Bunches large and loose; berries large, of a coppery red color ; vine hardy.

Champion-Bunch medium to large; berry large, round, black, very early; commence coloring July 18th.

Clinton-Bunches small and compact; berries small ; sprightly flavor; one of the hardiest and most prolific; a rapid grower; should hang late on the vine. Price 10 cents each.

Concord-Bunch large and heavy shouldered; berries large, round, black, with a blue bloom. Its capability to suffer hard usage and neglect, its productiveness and freedion from disease, the early and uniform maturing of the fruit, make it one of our most popular grapes.

$\checkmark$ Conqueror-Bunch long, loose shouldered; berries medium, glossy black with a fine bloom: flesh slightly pulpy, juicy, sweet; very productive and hardy. New. Last of August.

$\checkmark$ Cornucopia (Arnold's No, 2) - Bunch large, compact, shouldered berry, above medium; very blạk, with a fine bloom ; flesh juicy, no pulp. August. 
Croton-Bunches large, shouldered; berries medium, light yellowish green, very handsome, juicy, sweet; ripens first of August.

Cynthiana-Bunch moderately compact, shouldered; berries small, round, black; blue bloom, flesh juicy, late in ripening.

Delaware-Bunches small and compact; berries small, light red; very sweet, tender, vinous and delicious; of the first quality.

Diana-Bunch medium to large, compact; berries medium to large: pale red, juicy, sweet and good.

Dutchess-White grape of medium size; large, shouldered bunches; good flavor; strong grower. Price 50 cents each.

Elsinburg - Bunches large; berries small; black, sweet; strong grower.

Wolia-Bunch large, compact, shouldered; berry medinm ; greenish white; flesh tender and sweet; vine of the most hardy character, grows readily from cuttings. A new seedling, originated by Robert Linville, Esq., of Forsyth County, N. C., and sent by him to me for trial, and has proved an interesting varjety. Seedling of Concord.

Eumelau-Bunch good size, compact, shouldered; berry medium; flesh tender, sweet, sprightly.

Golden Gem-Parentage Delaware and Iona; vine moderately vigorous; bunch small and sometimes shouldered; berry small and of rich golden color; flesh tender; juicy and rich, with a high, aromatic flaror; ripens before Hartford Prolific, and continues a long time in season. Price 50 cents each.

Hartford Prolific-Bunch and berry large; black, sweet and musky ; vine vigorous and exceedingly productive; very early.

Iona - Bunches large, shouldered, compact; berries large, round; skin thin, pale red; quality very good.

Israella-Bunches medium to large, compact; berries large, slightly oval ; black, tender, sweet and rich.

Isabella-Bunch and berry large; dark purple, juicy, sweet and very productive. Train to a wall.

Ives' seeding-Bunch medium, compact, shouldered; berries above medium, black, roundish, oval; flesh with some pulp, juicy and sweet. Very vigorous and productive.

Jefferson-A new red grape; vine hardy and vigorous grower ; bunch large, shouldered; berries large, roundish, oval, light red with a thin lilac bloom : sweet, slightly vinous, spicy. Price $\$ 1.00$ ench.

Jonesville - A very early black grape; not tested here, but highly recommended.

King-Bunch large, shouldered; berries large, round, clark red, şweet.

Lady-Color light greenish yellow, covered with white bloom; skin thin; pulp tender, sweet-and rich, slightly vinous; bunch medium; berries very large; ripens very early; strong growth : very desirable; one of our hardiest grapes in vine and fruit. Price 30 cents each. 
Lady Washington-Bunches very large, shouldered; berries medium to large size, of a light yellowish color, tinged with pink where exposed to the sun and covered with a light bloom; may be classed with the white grapes, ripening with Concord, and will keep until January.

Moore's Early-A seedling of Concord, which it equals in vigor and hardiness of vine. Bunch large; berry round and large; black, with a lieavy blue bloom; quality better than Concord, and ripens from ten days to two weeks earlier. Price 50 cents ${ }^{\circ}$ each.

Martha-Bunch medium, shouldered; berries large, greenish yellow, with a bloom; quality better than Concord, from which it has been raised; a fine, hardy white grape.

Maxatawney-Bunches medium, shouldered; compact; berries large, oval, white, juicy.

Niagara-Ripens with the earliest, does not drop from the stem, does not crack; clusters large, compact, sometimes shouldered; berries very large, hang long on the vine, which retains its leaves fresh and green till late in the season; color light greenish white, semi-transparent; good flayor, little pulp, melting and sweet to the center; vine hardy, strong, thrifty grower and profuse bearer. Price $\$ 1.00$ each.

Norton's Virginia - Bunches long, loose; berries small, no pulp, vinous; vigorous and productive; one of the finest wine grapes.

Prentice-White, best quality, early good grower, very productive, hardy, good keeper; a native seedling with no foreign blood ; flesh tender, sweet, melting, juicy, with a pleasant, musky aroma; quality of the best Ripens with Concord. Price 50 cents each.

Perkins-A large, handsome grape; ripens early, sweet, pulpy, foxy ; very hardy; vigorous, healthy and productive.

Rebecca-Bunch medium, compact, shouldered; berries above medium, oval, amber color, flesh juicy, sweet; a slender grower and profuse bearer.

Pocklington-A new, fine, showy, extremely hardy white grape; vine a strong grower' clusters large and compact; quality sweet and good; ripens with Concord. Price $\$ 1.00$ each.

Salem - Bunch large, broad and compact; berry large, oval, of a light chestnut color; skin thin; flesh tender; very sweet and sprightly; vine hardy.

Scuppernong - Bunches small, loose; berrries round, large; skin thick, light green; flesh pulpy except when thoroughly ripe, juicy and sweet. It needs no pruning, is subject to no diseases, produces certain and enormous crops, and makes good wine. No fruit garden, however small, should be without at least one vine. One year layers, 25 cents each. 'Two year layers, 50 cents each.

Secretary-Bunch large to very large, shouldered, a portion doubleshouldered, rather loose; berry large, round, oval; skin thin, tough, black, blue bloom; flesh mealy, tender, juicy and sweet, slightly vinous, slightly aromatic. Very best in quality for the amateur. Price 50 cents each.

Senasqua-Bunch large, often shouldered, compact; berry large, round; skin deep black; flesh firm, tender, juicy, sweet and rich; vine vigorous and hardy. New. Last of August. 
Seneca-

Telegraph-Bunch above medium to large, compact; berry large, round, black; flesh juicy with some pulp; vine hardy and vigorous. Early.

Union Village-A very vigorous grower with immense foliage, productive bunch, and berry very large; flesh free from hard pulp, tender; juicy, vinous, pleasant.

Walter - Punch medium, shouldered, moderately compact; berries medium light red; flesh juicy and sweet.

Wilder-Bunch large and compact; berries very large; deep blue black; flesh tender, juicy and sweet. Last of August.

Vergennes-Vine vigorous, healthy and hardy; bunch and berry large; a beautiful red grape, ripening early-before the Hartford-and keeps readily in common cellars until April, and it is claimed that if placed in a dry room it will dry into perfect raisins, and is a good shipper, the value of which is beyond estimate for home or market use. Price 50 cents each.

Worden's Seedling - Bunch large, compact and very handsome; berry larger than Concord; good flavor; vine hardy, vigorous and productive. Ripens early.

York Madeira--Ber'ry mediun size, roundish, oval; thin skin; acid center, juicy, very sweet and pleasint flavor.

White Ann Arbor-A new, handsome, white grape; hardy in every respect; a good bearer; never mildews nor rots; ripens two weeks before Concord. Price $\$ 1.00$ each.

\section{SPECIAL LIST.}

The President of the North Carolina Horticultural Society called a meeting which met in Raleigh, X. C., in December, 1885, having for its object, in part, the examination of the new and old fruits of the State, in order that the Society might take some action in revising the lists of North Carolina fruits for general planting. The הecretary had previously sent out circular letters to the different sections of the State, inviting all fruit growers to bring in any new desirable varieties, or any nice samples, old as well as new sorts. Whereupon the varieties voted on and approved as most especially desirable for general planting, and of which specimens were sent from these Nurseries and laid before the meeting, were, of apples: Maryland, N. C. Keeper, Merit, Buckingham, Magnum Bonum, Ben Davis, David's Winter, Angell's Favorite, Limbertwig Red, Limbertwig Royal, Red Cheese, Virginia. Shockley, Virginia Beauty and Wine sap. The voting was also continued on varieties not on exhibition, and the following list was arlopted: American Summer Pearmain, Early Harvest, May, Red June, Summer Rose, Yellow Horse, and Sine Qua Non, Sweet Bough, Yadkin Beauty, Green Sweet and Harper's Seedling should have been added to the list by all means.

Of peaches, the following were roted in as most desirable for general orchard planting: Albright's Late, Alexander, Chinese Cling, Crawford's Early, Crawford's Late, Dyer's June, Early Beatrice, Early Louise, Early Rivers, Early Tillotson, Eaton's Crolden Cling, Heath's Cling, George IV., 
Mitchell's Mammoth Cling, Morissania Pound, Musser, Old Mixon Cling, Old Mixon Free, Red Cheek Melocoton, Steadly, Stump the World, Saunders, Thurber, Waterloo and Yellow Rareripe.

Of Grapes, the selection was as follows: Brighton, Champion, Clinton, Concord, Delaware, Hartford, Ives, Lady, Martha, Norton's Virginian, Salem and Worden's Seedling.

As to Pears, by the test here in our own orchards, out of over forty varieties, we can safely recommend the following as good: Bartlette, Bloodgood, Doyenne D"Ete, Louise Bonne de Jersey, Seckel, Tyson, White Doyenne, Beurre Clairgeau, Beurre d'Anjou, Dutchess d'Angoleme, Howell, Souvenir du Congress, Beurre Easter, Doyenne D'Alencon, Lawrence, Vicar of Wakefield and Salem.

'T'o give a special selection of Cherries as tested here we place as best: Black Eagle, Black Tartarian, Early Purple, Elton, Florence, Gov. Wood, Great Bigarreau, Napoleon, Dr. Wiseman, Early Richmond, May Duke, Amber Bigarreau and Coe's 'Transparent.

\section{CURRANTS.}

Currants can be used in so many ways for making tarts, jellies, wines, dc., that every family should have a few bushes. One or two dozen well cultivated. on a rich soil, will supply any ordinary family.

\section{PRICES.}

15 cents each. - - - $\$ 1.50$ per dozen.

\section{Varieties.}

Black Naples-Fruit large and fine; yery productive.

Cherry Red-Very large; one of the largest red currants.

Red Dutch-An old, well-known sort; a great bearer, of ,good quality:

White Dutch-Berries large; yellowish white; bnnches long, much less acid than any of the red currants; very popular; the best white currant.

White Grape - Berries very large; bunches leng, whitish yellow, sweet and good.

\section{GOOSEBERRIES.}

The (rooseberry should have a rich, moist soil. It should be pruned annually by thimning out the branches, and the ground should be well mulched.

\section{PRICES.}

15 cents each. \$.50 per dozen. 


\title{
Varieties.
}

Downing's Seedling - A large and excellent variety.

Houghton's Seedling - Medium size; pale red; flesh tender and good; vigorous and prolific.

$\checkmark$ Mountain Seedling-Larger than Houghton's; good flavor; vigorous and productive.

\section{RASPBERRIES.}

The Raspberry requires a rich, mellow soil. Keep the ground free from weeds, and cut out all the old canes immediately after the bearing season is over, letting two or three strong suckers grow for the next year's bearing canes.

\section{PRICES.}

\author{
$\$ 1.00$ per dozen.
}

\section{Varieties.}

Clark-Fruit large, conical, regular ; bright crimson ; flesh rather soft, juicy, sweet and fine.

$\checkmark$ Doolittle Black Cap - Canes vigorous, very productive and early; fruit large, black and firm.

Davison's Thornless - Canes smooth, without thorns; fruit early, black, sweet and fine.

$\checkmark$ Mammoth Cluster-Fruit large, with a rich, purple bloom ; juicy and sweet; riperis late.

Miami Black Cap-Fruit large, brownish black, keeps in bearing a long time; very few thorns on the canes.

Philadelphia - Fruit medium size; dark crimson or purplish red; flesh moderately juicy, good; canes hardy and prorluctive.

\section{STRAWBERRIES.}

The Strawberry is the earliest and most delicious of the small fruits, and can be grown successfully on every variety of soil, if dry. and is so easily cultivated that every garden should have a good bed. Plant on a rich soil and cultivate during summer and winter. As soon as the ground commences freezing, mulch lightly with coarse manure on the plants and straw between the rows heavily, to remain until the crop of fruit is off. Mulching protects the plants in winter and retains the moisture in summer, which causes the fruit to grow extremely large and keeps the berries clean when ripe. Two or three hundred plants will supply any ordinary family with this delicious fruit four weeks before the other small fruits come in. 


\section{PRICES, unless otherwise noted.}

20 cents per clozen. - - - : $\quad \$ 2.00$ per hundred.

\section{Varieties.}

Agriculturist - Fruit large size, conical and somewhat flattened; dark crimson; firm and of fine flavor.

Barnes' Mammoth-Fruit very large, roundish, obtuse, surface somewhat uneven; crimson; flesh scarlet, firm, juicy, sprightly, sub-acid.

Boyden's No. 30-Fruit very large; bright crimson; Hesh firm, juicy and rich; very rigorous and productive.

Champion, or Windsor Chief-A new berry, highly praised. It is rather regarded as one of the best and richest in flavor by those who like an acid berry. It is a little soft like Charles Downing and some other.fine varieties.

Charles Downing-Large, nearly regular, conical; deep scarlet; flesh firm, juicy, sweet and rich.

Crescent Seedling--Medium to large size, conical, uniform; bright scarlet and beautiful; ripens a few days in advance of $W$ ilson. The plant is a most vigorous grower, taking entire possession of the ground independent of weeds and grass. Very desirable and profitable.

Cumberland Triumph-It is a strong, splendid grower, making enormous stools, and producing fruit of mammoth size and regularly so. Price 50 cents per dozen.

Downer's Prolific - Fruit large, nearly round; light scarlet; flavor good; a very early variety.

French-An early variety, of beautiful scarlet color; flavor very delicious; uniformly large and extremely hardy.

Glendale- Very productive; berries light colored, very firm ; desirable only on account of firmness. Price 50 cents per dozen.

Green Prolific - Fruit large size and very uniform, round; beautiful scarlet; fine flavor.

Golden Queen - Fruit very large; yellowish red; tender and fine flavored.

Jocunda-Fruit large. conical; brilliant scarlet color; flesh white, firm and solid; of an excellent flavor, juicy and rich.

Lenning's White--Medium size, round; white, with a rich, delicate blush on one side; high flavored.

Longfellow-A magnificent berry of great excellence; plant very strong grower, forming large stools; berries, uniformly large, frequently measuring two inches and more in length and very beautiful in appearance, with fine flavor; ripens thoroughly all over at once; does not damage if left on the plant for some days after being ripe. Price 50 cents per dozen. \$2.00 per hundred.

Manchester-Berry firm, uniform in shape which is roundish, conical ; ripens in every part and averages above medium as long as it remains in fruit, of good quality, hardy and immensely productive. 
New Jersey Scarlet - Fruit medium, conical; light, clear, scarlet; flesh moderately firm, juicy, sprightly, sub-acid.

Sharpless - This is undoubtedly the great leading berry for size at present. it being a magnificent grower, and yielding extremely large crops of immense size, beautiful berries under good culture. I would recommend it. after a thorough test made here, as the most profitable berry grown to my knowledge, of the very best quality and very largest size. 50 cents per dozen. \$2.00 per hundred.

Triumphe de Gand - Very large, conical, often flattened; glossy ; crimson, flrm, hardy.

Wilson's Albany - Large, roundish, conical; color dark crimson; flesh firm and of fair quality; hardy and very productive; excellent.

\section{Does Fruit Growing Pay in North Carolina?}

SHALL WE PLANT APPLE, PEAR, PEACH, CHERRY AND OTHER FRUIT TREES, GRAPEVINES, STRAWBERRIES AND OTHER SMALL FRUITS?

Will my many friends and patrons allow me to say a few words on this subject:

I do not propose to claim that fruit growing will bring a fortune to each and every person engaging in that occupation, but the evidence is plain to me on every hand, that fruit growing in North Carolina does pay a rich reward to every land owner that engages in it, to the full extent of home supplies, if nothing more. We must realize the fact that the wives and little ones are obliged to spend most of their time at home, and consequently if there is any place on earth that should be beautiful, pleasant and enticing, it should be our home surroundings. And what better way can the common tiller of the soil get about it than to plant trees and vines to hang weeping during the summer and autumn, with their beduti.ul crimson and golden fruits; and when the autumn comes gather and store away of the harvest of fruits in our cellars in such quantities that it will not be exhausted until a new crop of fruit is ready to commence to harvest. Many a child with a love for his home, has been disgusted and driven into other countries because the home surroundings were so destitute of attraction. Fruits will make home attractive, pleasant and enticing, and it is not expensive to beautify homes with.

The children love to gather and eat fruits, and the middle-aged and the old people love to wander amongst the trees and vines loaded with beautiful ripe fruits und pluck and eat; and fruits are admitted even to the sick, in many cases, when no other food could be taken by the patient.

The writer has received many orders in winter and late in the spring, for fresh green fruits for persons on a sick bed, who could not 
be expected to live,-asking for only the smallest quantity, if I did not have it in abundance, saying that the sick person could take no more food or medicine; and in every such order it has been filled with the best of ripe fruits, and in every case the sick parties receiv. ing great benefit. and in no case did any injury result from eating the ripe fruits properly prepared for the sick. One of God's grand. est earthly blessings is surely the good fruits of our land, of which North Carolina can be made a home for most all of our American and many foreign sorts.

For a common family, a two rod square of ground properly planted to our largest and most productive strawberries, for instance the Sharpless and Crescent, is amply sufficient for a three or four weeks' supply; and then come our fine Cherries, the Dr. Wiseman frequently as early as the Strawberry, and the Black Tartarian, May Duke, Governor IVood, Great Bigarreau, Elton, Napoleon, Amber Bigarreau, Early Richmond and also Blackhearts and Morellos, ripening in succession from the first of May until the last of June, and can be grown in yards and along.roadsides where shade is wanted; and it is but little trouble to sell all surplus cherries in almost any section of country, near railroads, at from to to 20 eents per quart; many reliable reports have reached me where $\$$ io to $\$ 20$ per tree, in a single year have been realized, and many reports of much larger income from single trees in one season.

Next coming in rotation of profitable fruits, are our early peaches which have proved a rich reward to all engaged in peach growing for market, who were located near railroad shipping facilities for Northern sections of our country, often receiving according to reliable reports, from $\$ 100$ to $\$ 200$ and $\$ 300$ clear profit to the acre, planted in peach trees and properly cared for.

As to Apple tree planting, we never hear it questioned as to the great profit of apple orchards when proper selections were made at planting time, it being an easy matter with care in gathering and storing our best keeping apples, to have an assortment of them fresh and sound in our cellars through the entire winter and into spring, until our early apples come into ripening. But the local nature of the apple makes it of the greatest importance to give thought before planting the apple orchard, as to what varieties are best suited to our section of country. Considering the immense number of winter apples catalogued in American catalogues, comparatively few of them are desirable or of value to plant in North Carolina as winter keepers.

The Strawberry, Cherry, Peach, Pear and Grape, almost any variety that will succeed in Virginia, Pennsylvania, New York and New Jersey, will succeed in most sections in North. Carolina. But not so with the apple. Many have dearly learned the lesson by buying entire orchards of young trees, which proved entirely unsuited to their section, - varieties which originated far away and had never been tested in their locality, and hence a failure-large orchards bearing no fruit as to profit.

The pear is not so local in its nature; but to plant a pear 
orchard without learning of the most successful varieties, as a market fruit, will surely prove a failure as to profit; but with the proper selection, care in pruning, cultvation, etc., pear growing cannot fail to be profitable on all our railroad lines, especially near the cities, as at no time our pears fail to be ready sale at from $\$ 4.00$ to $\$ 6.00$ per bushel.

The grape, the value of which has not been appreciated generally here in North Carolina until lately, has every indication in the future of adding great wealth to our State. The time was when grape growing could not be depended upon; but the day has come, since so many varieties of great value have been recently originated, taking the place of our older worthless sorts, that grape growing has become one of our most profitable industries. Many statements from reliable sources could be produced to show enormous profits from single acres planted to grapes, besides the great pleasure to a family to pluck the ripe clusters from the vine on their own grounds. Who that has enjoyed the pleasure of visiting a vineyard londed with ripe clusters of such grapes as the Concord, Hartford Prolific, Delaware, Martha, Lady Washington, Lady and Brighton, and many others of finer reliable grapes, would for a moment consent to do without such pleasures and great profits which can be derived from our fruits.

The outlook for North Carolina fruit growers is now favorable, and no doubt those who have a fancy for this business may enter upon it with confidence that their efforts will be crowned with success.

Shall we not have those bounties and beauties of creation which have been given us for so little trouble and labor and which is such a blessing to our country?

N. W. CRAFT,

SHORE P. O., Yadkin County, N. C. 


\section{ORN AMENTAL TREES.}

Balsam Fir - A very fine and favorite Evergreen for lawns and door yards; fine form, of vigorous, upright habit and rapid growth. 10 to 12 inches high, 50 cents each.

Norway Spruce - An elegant, lofty tree; extremely hardy and of rapid growth; one of the most popular, large-growing evergreens for ornamental planting, and well adapted to this climate. 10 to 12 inches high, 50 cents each

Tree Box - A beautiful, slow-growing evergreen; a very desirable small tree for gardens or yards a single specimens to themselves or grown in hedges, properly clipped, are beautiful trees. 50 cents each.

Dwarf Box - A slow-growing evergreen, which will; when closely planted in rows, make a beautiful edging for walks in yards or gardens; can be grown in any shaped hedge desired by proper clipuing. Price 25 cents each.

\section{ORDERS FILLED BY MAIL.}

Any one ordering one dollar's worth or more at a time of Grape Vines or Strawberry Plants, I will send them by mail, post paid, to your Post Office, at prices herein stated, packed in moss, so as to reach you in good condition. Order by mail if you are not near a Railroad station, if my agents do not call on you.

Direct all orders or inquiries, plainly written, to

$$
\text { N. W. CRAFT, }
$$

Shore P. 0., Yadkin County, N. C. 


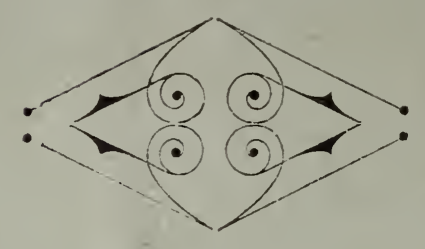

\section{NGARMAN GARPO2}

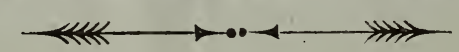

On my Nursery Grounds and in connection with them I have erected Three Well Arranged Fish Ponds; and have them stocked with the Pure Scale Carp, and will be able, as they increase, to supply my many customers who might wish to stock ponds. In consequence of their vast increase a pond is soon stocked, and their extraordinary quick growth soon renders them fit for the table. As a food fish they afford a most palatable dish.

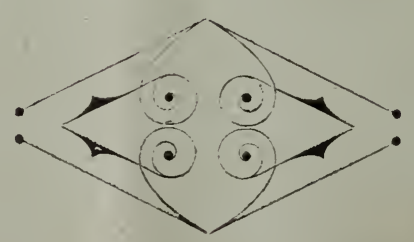

